\title{
NDIGO BUNTING AT GOOD SPIRIT PROVINCIAL PARK, SASKATCHEWAN
}

ON JENSEN, 1828 - 8th Avenue North, Saskatoon, Saskatchewan, and DON WEIDL, 337 Avenue D South, Saskatoon, Saskatchewan

In 1977 the Saskatchewan Natural History Society held its annual ummer field meet at Yorkton. As sual the event was successful and njoyed by all. One of the highlights $f$ the outing for us was the sighting $f$ an Indigo Bunting at Good Spirit rovincial Park.

Wayne Harris and Sheila Lamont old us that on the morning of June 1, they had heard and seen a bird lat resembled a bunting near the rst overflow campground. They ere unable to get a good look at it ecause of poor light, thus only a lhouette was observed. The four of returned to the area late that afterpon to try and find the bird, but ere unsuccessful. At approximately 00 on June 12, the authors again turned to the area to find Bob odwin with whom we spent about minutes listening for the bird but, sain, we were disappointed. The thors then left to look at an Eastern ood Pewee that was recorded near e park entrance the previous day. approximately 0745 , we observed a ale Indigo Bunting, perched on a ad branch at the top of a trembling pen (Populus tremuloides). We idied the bunting for about five nutes during which it sang several nes. Ron Jensen photographed the d, using a $35 \mathrm{~mm}$ camera and telephoto lens. At 0805 we told Bob Godwin and Moray Lewis of the sighting, and they came with us to the area. The bird was again heard and seen several times. At 0815 the Indigo Bunting stopped singing and flew into the bush. Bob Godwin returned to the area later in the day and flushed a male and female from the shrubs along the roadside. In later correspondence with Wayne Harris, he states that because of the distance between the sighting he had on June 11 and the sighting we had on June 12 , these are probably different birds.

Godfrey describes the immature male (first breeding plumage) as similar to adult male in breeding plumage but blues less pure; coverts with some brown. ${ }^{7}$ The distinguishing feature of the male Indigo Bunting we saw on June 12, besides the blue color, was the brown wing coverts.'

Other records for the Indigo Bunting in Saskatchewan are summarized in Table 1 as follows. Two hybrids between Indigo and Lazuli Bunting were collected in 1965 at Kenosee Lake. ${ }^{5}$ The first, collected on June 4 , had predominantly Lazuli Bunting features. The second, collected on June 18, had Indigo Bunting features predominating.

Table 1: INDIGO BUNTING RECORDS FOR SASKATCHEWAN

\begin{tabular}{|c|c|c|c|c|}
\hline e & Area & Birds & Observer & Reference \\
\hline $\begin{array}{l}\text { e, } 1890 \\
\text { y } 28,1893 \\
\text { e } 23,1927 \\
.27,1941 \\
\text { e } 22,1953 \\
.1961\end{array}$ & $\begin{array}{l}\text { Indian Head } \\
\text { Estevan } \\
\text { Armley } \\
\text { Good Spirit Lake } \\
\text { White Bear } \\
\text { Saskatoon }\end{array}$ & $\begin{array}{l}2 \text { seen } \\
1 \text { specimeno } \\
1 \text { pair seen } \\
1 \text { record } \\
10 \text { seen } \\
1 \text { banded }\end{array}$ & $\begin{array}{l}\text { George Lang } \\
\text { D. L. Thorpe } \\
\text { M. G. Street } \\
\text { W. A. Tripp } \\
\text { S. O. Jordheim } \\
\text { Florence Richards }\end{array}$ & $\begin{array}{l}5 \\
9 \\
3 \\
2 \\
4 \\
-\end{array}$ \\
\hline $\begin{array}{l}1,1967 \\
\mathrm{gg}, 1976\end{array}$ & $\begin{array}{l}\text { Aylsham } \\
\text { Qu'Appelle Valley }\end{array}$ & $\begin{array}{l}10 \text { seen } \\
4 \text { seen }\end{array}$ & $\begin{array}{l}\text { Mrs. M. Robin } \\
\text { F.W. Lahrman }\end{array}$ & $\begin{array}{l}7 \\
8\end{array}$ \\
\hline
\end{tabular}


'GODFREY, W. E., 1966. The birds of Canada. Nat. Mus. Canada Bull. 203. Queen's Printer, Ottawa.

${ }^{2}$ HOUSTON, C. S., 1949. The birds of the Yorkton district, Saskatchewan. Canadian Field-Nat. 63:215-241.

${ }^{3}$ HOUSTON, C. S., and M. G. STREET, 1959. The birds of the Saskatchewan River. Sask. Nat. Hist. Soc., Spec. Publ. 2.205 pp.

${ }^{4}$ JORDHEIM, S. O., 1953. Indigo Bunting. Blue Jay 11(3): 10 .
${ }^{5}$ MITCHELL, H. H., 1927. Birds of Saskatchewan. Canadian Field-Nat. 38 101-118.

${ }^{6}$ NERO, R. W., and M. R. LEIN, 1971. Bird of Moose Mountain, Saskatchewan Sask. Nat. Hist. Soc., Spec. Publ. 7 $56 \mathrm{pp}$.

${ }^{7}$ ROBIN, M., 1967. Indigo Bunting a Aylsham. Blue Jay 25:146.

${ }^{8}$ SERR E. M., 1976. Northern Grea Plains. American Birds 30:969-971.

${ }^{9}$ SETON, E. T., 1908. Recent bird record for Manitoba. Auk 25:450-454.

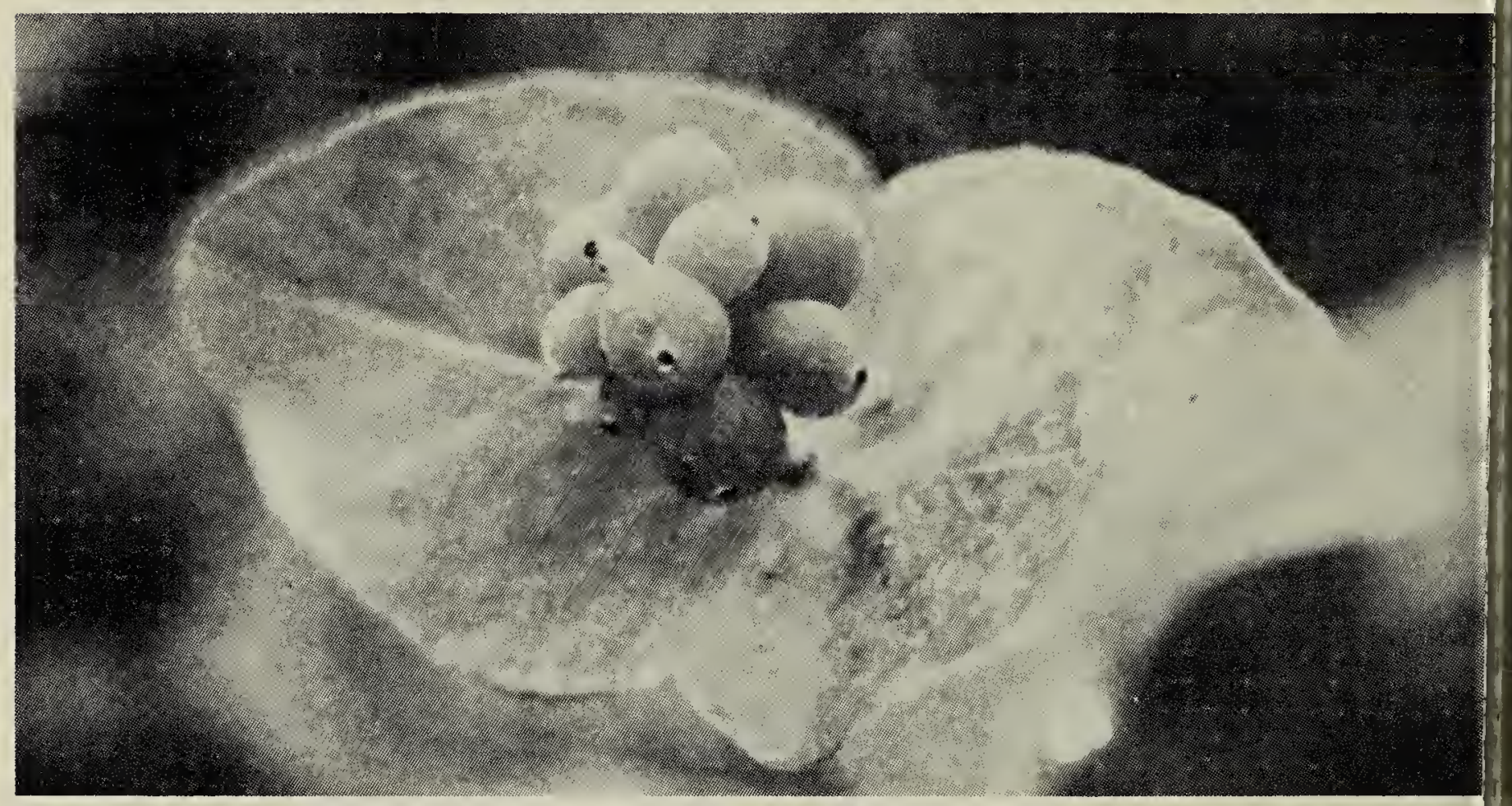

Twining Honeysuckle

Bernard deVri

\section{EUROPEAN WIGEON IN SASKATCHEWAN}

\section{F. M. BRIGHAM, P.O. Box 3240, Station C, Ottawa K1Y 4J5}

On April 27, 1977, J. D. Lafontaine and I saw a male European Wigeon at the east end of Cypress Lake, Saskatchewan. The bird was studied for 5 minutes with a 20x-40x Bushnell Zoomscope at a distance of about 100 $\mathrm{m}$. The bird was seen in the air and then as it fed in short grass on a wet flat. The rusty head with buffy forehead and crown, blending with an all-gray breast, sides and flanks and the white upper wing coverts were clearly visible in the sun. Americi Wigeons were nearby during part the observation period. While field guides were available, thr. nights before we had studied an e cellent photo of a male taken Lafontaine in B.C.

EDITOR'S NOTE: There are previc Saskatchewan records for Cumberla House (a pair on May 7,1971 ) and Moose Jaw (one on May 23, 1977). 